\title{
TOURISM AND MANAGEMENT - A CHALLENGE FOR WOMEN
}

\author{
M.Sc. Azra Ahmetović1 , Doc. Dr. Nedžad Azemović², \\ ${ }^{1}$ Ekonomsko-trgovinska škola, Novi Pazar. \\ ${ }^{2}$ Privredna akademija, Novi Sad.
}

\begin{abstract}
The tourist trade and tourism management represent a special challenge to women. If this is the century of tourism, and if this is the time of "pink-collars" in management, that is, an invasion of female managers, then the domination of women in this industry can truly be expected. The authors point to numerous trends in tourism development that women have successfully embraced. Inevitable questions arise in the Balkan region: Is there a fear of strong women? What is the business style of female managers and what advantages do female managers have over their male counterparts? The authors seek the answers to these and other questions through case studies.
\end{abstract}

Key words: female manager, tourist trade, tourism management, business style.

\section{Introduction}

Big and radical and everyday changes contain some innovations in communications among people sexes and professions there are fewer and fewer differences among typically male and female jobs and there are more and more women on managing positions in politics, public institutions, culture and economy. Some traditional barriers have been knocked down, although not yet completely. Writing about women on managing positions, women who are on the highest positions in companies in tourism, is not easy at all. In professional literature there are very few written texts and very few themes are dedicated to a woman as a manager so, we can conclude that a woman is discriminated against men even in this regard. Because her position and role have been changing, she through centuries, it is expected that will get her position in $21^{\text {st }}$ century, in the century of changes and the fact that women are equally good at managing as men are, will be accepted.

\section{Tourism and management- a challenge for women}

Today 164 years after the pioneer role of Thomas Cook tourism has become a large public need, something without which we can't imagine the man's existing in this "fast world". Even the old oriental proverb says: "you don't need to live, but you must travel". It shows how necessary tourism has become to a man, regardless the fact that only one third of the mankind have enough money and can travel.

Tourism is not a simple group of activities. It means the constant interaction among people permanent contacts and services. As a public and economic occurrence, it is in the process of strong changes. It's complete affirmation and massiveness tourism reached in the after-war period thanks to the growth of standard of living and free time. So, the number of tourists between 1950.and 2000. increased 27,9 times in international movements while the income of international tourism unappeased 226 times during the same period of time (Jovicic: 2003).

Those who work on tourism market especially those more powerful, have stronger impact on the consumers in tourism then in other fields. Tourism is interpersonal people contact face to face. That's why people working in tourism should know that they have a great responsibility because they work with people cultures landscapes but above all time that is the most precious to a man, his free time (Popesku: 2002).

In a tourist economy company carrying out of commanding managing, business and processes are provided. A man or a woman manager runs the business through other people, runs carrying out individual jobs and tasks or is decupled either with the development of some organized department or a company as a whole. Such a person is expected to achieve the development of the firm that is to enable the realization of it $^{\mathrm{s}}$ basic and strategic goals. 
The manager of a current or future company of tourist complex can't develop the authentic professional career without developing the real proportion between the four fields: creation, knowledge and techniques efficiency and human values (Figar: 2001).

Management should understand to be the process of creating and maintaining of the needed conditions where the individuals, acting through organized groups, achieve the predicted goal. The achieving of that goal is based on knowledge and empiricism (Stefanovic: 2004).

\section{Is there fear of strong women?}

Entering $21^{\text {st }}$ century means the increases number of women in management especially in the top management of a tourist company. Women managers are making the new way of running a business and while doing that they don't take over the skills attitudes and habits of mien. It means that they are making their own style of management and behavior toward the employees. In that way they show that nontraditional ways of management can be very successful in the world of business.

The following results have been obtained in the international Women's Forum

Research (Harvard Business review: 1990):

- Women-top managers earn the same amount of money per year as men do in tourism or some other profitable areas so the fact that there is a big gap between their profits cannot be acceptable.

- Only 39\% of men managers have wives who are employed, while $71 \%$ of women managers are married to employed man. Because of that their mutual annual income is much bigger than the income of men managers and their wives.

- Women base power and authority on their success made on contacts with employed people.

Except physical biological differences between sexes there are much prominent psychological differences which can be seen in their behavior towards other people, the way they run business, the way they lead and direct people. The differences are numerous and evident and every human being should be aware of them all this life.

The basic problem is that men are used to see women as mothers, sisters, girlfriends, wives, lovers and mainly as objects and hardly as equal business partners.

Some men even declare that they feel embarrassed when doing business with women managers.

The biggest minds in psychology made their own views of women by analyzing their behavior, characteristics and the way they react. In order to understand and get to know closely the behavioral an energetic business woman in tourism you should get to know closely her psychological individual characteristics. This is the way some experts in psychology describe a woman.

Sigmund Freud had his theory if a woman wants to be a woman, she must possess a certain extent of masochism, passiveness, vanity, envy, jealousy (especially of men) and some defects of her super-ego.

Karl Gustav Jung was much wiser and suggested to women to reveal investigate and inspire their "animus" (the masculine part of a women's psyche, in essence of her femininity). 
Jin Sikoda Boleu, Jung's successor thinks that a woman can integrate to those numerous paradoxes as in herself and to be sweet, charming sensitive, but as the same time to be brutal while making adequate professional decisious. She can be:

- a woman - a fighter and daddy's daughter who defends patriarchal principles better than many men,

- a woman - a little girl and mammy’s daughter who glorifies matriarchal wisdom,

- a woman- mother and wife who represents the gray eminence of the family even the firm,

- a woman- sister and successful competitor in male sports and a hunter of professional trophies,

- and of course, we mustn't forget a woman-a lover who is able to draw out what is best in a man, to inspire him with unseen projects but at the same time to become his nightmare of caprice, selfishness and Machiavellism.

- we shouldn't even forget a woman -a saint who is always ready to give wise advice and is an encouraging example of the fact that all women are not the same (Stefanovic: 2000).

One of the problems that a woman has nowadays is that she is not satisfied with just one role. Contemporary life has changed woman's role and she is expected to be equally good at work and at home which is, for a woman-manager of a tourist economy company another challenge. She is persistent stubborn, well organized, thorough and succeeds to reconcile the expectations is asked for both at work and at home.

How can we then allow the women "the citizens of the second rank (class)" to become the top managers in the serious world of business. Who can allow that to them? Stressed prejudiced confused men afraid of strong women?

Men keep together while women are often used manipulated to be the pawns in male wars and then they ask men for support. Women must be more connected in order to make progress in their careers-says Kerol Bark. While Pamela Reis, one of the successful business women, gives her female students of the last year of economy the list with about ten names of successful women they can ask for support information and advice. This complicate and interesting question inspired me to conduct a poll on the theme how men-manager see a successful business woman on managing positions in our surrounding. One hundred businessmen from Nis, Pirot and Prokuplje were asked for their opinion. The results are unofficial and here are there.

Table 1. How men-manager see a successful business woman on managing positions in our surrounding.

\begin{tabular}{|l|l|c|c|}
\hline & Question & Yes & No \\
\hline 1. & Do you think that women can be good managers as men are? & $13 \%$ & $87 \%$ \\
\hline 2. & $\begin{array}{l}\text { Would you rather negotiate with a woman manager on the same hierarchy } \\
\text { level with yours? }\end{array}$ & $3 \%$ & $97 \%$ \\
\hline 3. & Would you prefer your superior to be a woman? & $15 \%$ & $85 \%$ \\
\hline
\end{tabular}


ISSN 2661-2666 (Online) International Scientific Journal Monte (ISJM)DOI: 10.33807/monte.202004653

Volume 2. No. 1 (2019): April

\begin{tabular}{|c|c|c|c|}
\hline 4. & Would you rather choose a woman for your first associate? & $21 \%$ & $79 \%$ \\
\hline 5. & Would you like your wife to be a woman manager? & $13 \%$ & $87 \%$ \\
\hline 6. & Would you like a woman manager to be your lover? & $58 \%$ & $42 \%$ \\
\hline 7. & Would you like a woman manager to be your mother? & $9 \%$ & $91 \%$ \\
\hline 8. & Would you like a woman manager to be your daughter? & $41 \%$ & $59 \%$ \\
\hline 9. & Do you think that a woman manager can take as much as you do? & $39 \%$ & $61 \%$ \\
\hline 10. & Is a woman manager capable of dual career? & $17 \%$ & $83 \%$ \\
\hline 11. & $\begin{array}{l}\text { Does a woman clear her way towards success more by charm and her beauty } \\
\text { than by other qualities? }\end{array}$ & $89 \%$ & $11 \%$ \\
\hline 12. & Is your wife responsible for your success? & $35 \%$ & $65 \%$ \\
\hline 13. & What is the most valuable with a woman manager? & $\begin{array}{l}1 . \\
2 . \\
3 .\end{array}$ & $\begin{array}{l}\text { eauty } \\
\text { hetoric } \\
\text { htellect }\end{array}$ \\
\hline
\end{tabular}

Such answers are of course unexpected and disastrous. It's difficult and it's a slow process to accept changes in these areas, but at the same tame they are not impossible. This is still a new profession and we should give them support and some time to show their qualities and let them swim in "manager " $\mathrm{s}$ " waters. The next chart shows no that there are fewer women in management.

Graphic 1. The sex of managers 


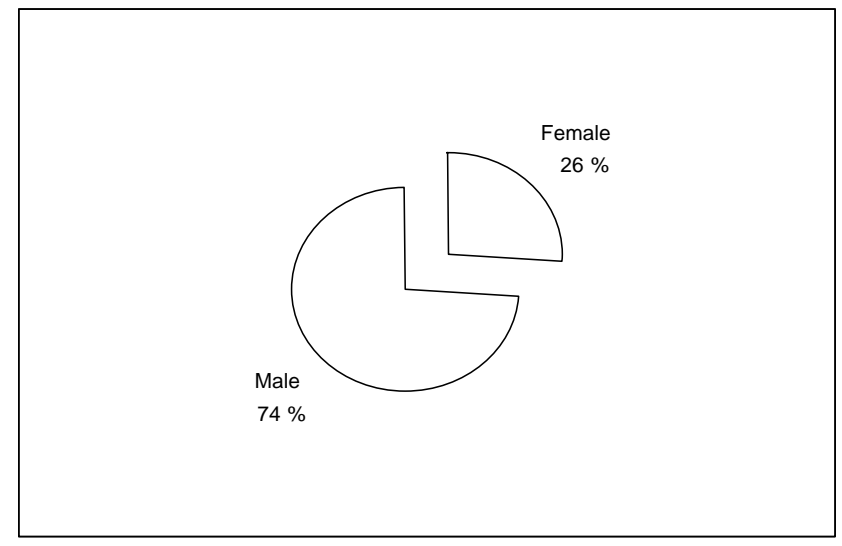

Source: Prof. dr. Pere Sikavica, Prof. dr. Fikreta Balitijarevic-Siber, Management- theory and a big empirical research in Croatia mass media, Zagreb 2004.

However, there are more and more women who are fighting for their positions and in other economical fields and they should be given the chance and support towards the fulfilling of their aim. Once you couldn't imagine a woman doing some job's but today there are a lot of women-successful surgeons, the owners of successful companies or women in politics. The rate of women having jobs from 1971 to 1998.raised from 56,8\% to 72,5\%, while the rate of men having jobs is slowly going down with a tendency of further decline (Torringhen: 2000).

\section{The business style of a woman-manager}

If a business woman in a tourist company identified herself with a business man, she would accept new patterns of behavior which are opposite to her nature and at the same time she would lose her own identity. That would show her down in making progress in her job where tact, cooperation and solving conflicts are required. At the same time a business man would have a good excuse for his critical attitude towards a business woman in tourism. A woman must remain a woman in business and must discover the authentic ways of power. The most authentic way of power of a business woman is her maternity which is more and more accepted in the world as the best business school.

In order to raise and educate children you need similar knowledge and skills as in business. They are: observation, consultations, giving directions developing habits, satisfaction of one's need's, learning and solving problems. At the beginning of 1990's a new style in business appeared which is a synthesis of male-female, wild gentle commanding styles. The period of integral extreme approach is appearing which represents the combination of the best things men and women do in business tandem.

Businessmen have chosen and created their own form of power. They have been accepted in business but they forced women to become stereotype in business for a long time. That's why women used defensive ways of power: charming, flattering, seducing and flirting not knowing that's not power but only techniques of control in order to feel more secure and more powerful. The other group of women accept the ways of power and the styles of management that men use. In that way they identify with men and use the power of authority. They long for career where control is distinct, they make decisions alone, express anger, swear in a word. They behave aggressively. They have chosen aggression in order to defend themselves from the influences of other people and to show their own power while in that way, they showed insecurity, endanger and helplessness.

Power is necessary to a successful business woman. It's a strong constructive power which make them active to finish their job successfully, to get respect and reputation and to create her own style in business. New task of a woman manager in a tourist company on her way up, is to discover and realize her own balanced style by which shy will avoid the traps of either too mild or too commanding behavior, that is the style which corresponds to her values expectations of her associates and business demands in a tourist company but, at the same time in harmony with the strategic aims of a tourist firm. That's necessary in order to: 
- make her personal contacts with her collegues and clients better --- make her associates work more effectively

- increase the productivity.

A successful business woman in a tourist company, who should make her own business philosophy, should be led by Aristotle's message: “He who hasn't learned to listen never will be a good commander". The advice to a woman manager, who is making her own business style can be built on the formula of the seven habits of successful business people and they are:

1. be proactive

2. Start working having in mind the aim

3. Put the most important things on the first place

4. Think about mutual benefit- "my victory-your victory"

5. Try to understand other people in order to be understood

6. Join your powers in a team

7. Sharpen your tools.

\section{An advantage of a woman manager in relation to a man manager}

To the question if there is any advantage of a woman manager of a tourist Company in relation to a man manager the answer would be positive. The first and the basic think is that the biological structure, emotional and other psychological hormonal differences certainly have influence on the fact that a business woman behaves differently than a business man. From those differences emerge certain advantages and they are (Maric: 2000):

(3) A business woman has a talent for an effective interpretation of nonverbal messages which occur in a business communication and gives her a significant advantage

(3) In a large number of situations along with all male analyses and prognosis of a job, making decisions intuitively is sometimes crucial; women are more intuitive than men,

(3) Women are biologically stronger which means they live longer and less suffer from so called professional diseases on which one should pay special attention: hypertension and heart attack. That means a woman is stronger to work on manager jobs than men are.

(3) Women are more persistent to realize certain business ideas. They reluctantly give up their ideas and they show that by their shrewdness (emotional intelligence). In business arrangements they often "go till the end" till the final success.

\section{Conclusion}

It's quite certain that the time of "pink collars" is coming that is the participation of women managers in tourism is increasing. If you take into consideration the fact that women contribute of tourism then you can rightly conclude that tourism and management are really attractive to women. 
ISSN 2661-2666 (Online) International Scientific Journal Monte (ISJM)DOI: 10.33807/monte.202004653

Volume 2. No. 1 (2019): April

\section{References}

Figar N. (2001). The bases in management, School of economics.

Jovičić D. (2003). Tourist regions, PMF

Marić J. (2000)." Differences and similarity between a woman and a man achieving the business success" conference "A business woman yesterday, today, tomorrow"-Economic council of Yugoslavia.

Popesku J. (2002). Marketing in tourism.

Stefanović V. (2000). A business woman yesterday, today and tomorrow, Conference "Economic conncie of Yugoslavia.

Stefanović V. (2004). Tourist management, PMF Nis.

Sikavica P., Bahtijarević-Šiber F. (2004). Management-theory and a big empirical research in Croatia masmedia, Zagreb.

Torringhen D. (2004). “Management of human resources”, Datastatus, Belgrade.

Veljić S. (2000). “How to become and stay a successful business woman”-consultation -“A business woman yesterday, today, tomorrow"-Economic council of Yugoslavia. 